\title{
Comparison of the diel and spatial distribution patterns of ichthyoplankton and ichthyoneuston in the Southeastern Brazilian Bight
}

\author{
Mario KATSURAGAWA \& Yasunobu MATSUURA \\ Instituto Oceanográfico da Universidade de São Paulo \\ (Caixa Postal 9075, 01051 São Paulo)
}

\begin{abstract}
- Abstract: Fish larvae were collected by neuston and bongo nets, in the Southeastern Brazil, during four oceanographic cruises (January 1980; January 1981; October 1981; and March 1982). The results are compared and analyzed in order to study the patterns of diel vertical distributions of fish larvae and to detect sampling problems. Larvae collected with neuston net were quite different in types and size composition, when compared with those collected with bongo net in oblique tows. Clear tendency of stratification in size composition at the uppermost layer can be observed on juveniles ( $>19 \mathrm{~mm}$ ) of Sardinella brasiliensis which also showed day time avoidance. Most of the neustonic taxa were also caught in the deeper layers, although some groups, e.g. Mugilidae, Mullidae, and Gerreidae, were more abundant at the surface. Density of ichthyoneuston is much higher than those observed in the Northwest Atlantic and number of fish larvae collected during the day by neuston net exceeded that of night samples.
\end{abstract}

- Descriptors: Ichthyoplankton survey, Neuston, Surface microlayer, Sampling, Plankton collecting devices, Vertical distribution, Southeastern Brazilian coast.

- Descritores: Levantamentos do ictioplâncton, Nêuston, Microcamada de superfície, Equipamentos para coleta de plâncton, Distribuição vertical, Brasil: costa sudeste.

\section{Introduction}

The neuston is a group of planktonic organisms which inhabit close to interface between sea surface and air and include such organisms as bacteria, protozoa, phytoplankton, zooplankton and some insect (Zaitsev, 1971; Levinton, 1982). According to Hempel \& Weikert (1972), the neustonic organisms can be classified into three groups : euneuston are the organisms which live in the vicinity of surface during most of time; facultative neuston are those which concentrate at the surface only during certain hour of day; and pseudoneuston are those which live mainly in deep layer, but occasionally come to surface. Due to peculiar conditions of this layer which receive constant contact with atmosphere, it became a real ecosystem with proper food web in which occurrence of specially adapted organisms are common (Champalbert, 1980). One of these specialized groups

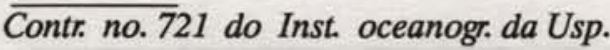

include eggs, larvae and juveniles of many fish species, therefore, this microcosms has called special attentions of ichthyoplanktologists (Ahlstrom \& Stevens, 1975; John, 1981). Larvae of some species are really neustonic, for example, many species of Mugilidae (Mugil cephalus, $M$. curema, Powles, 1981; Crenimugil labrosus, Liza sp, Tully \& ÓCéidigh, 1989), some Gadidae (Ciliata mustela, C. septentrionalis, Gaidropsaurus mediterraneus, Rhinonemus cimbrius, Tully \& OCéidigh, 1989), some Coryphaenidae (Coryphaena equisetus, C. hippurus, Powles, 1981) and some species of the family Exocoetidae (Gruber et al., 1982).

Plankton samples taken with conventional plankton nets, such as bongo net, conical-cylinder net, etc. fail to show this peculiar microcosm and tend to give some erroneous conclusion on their real importance. For this reason, several kinds of specially designed neustonic nets were developed for quantitative sampling (David, 1965; Sameoto \& Jaroszymski, 1969; Matsuo et al., 1976; Schram et al., 1981; Brown \& Cheng, 1981; etc). 
These neuston nets have similar structure, i.e. they have sledge-like frame with buoy and a rectangular net in the center of the sledge to collect upper ten centimeters. In spite of potential importance of neustonic study (David, 1965), there is no work made in the Brazilian waters.

This report presents a comparison of the ichthyoplankton assemblages taken with neuston and bongo nets in the Southeastern Brazilian Bight and discusses on their distribution patterns in space and time of day.

\section{Material and methods}

The Southeastern Brazilian Bight extends from Cabo Frio $\left(23^{\circ} \mathrm{S}\right)$ to Cabo Santa Marta Grande $\left(29^{\circ} \mathrm{S}\right)$ within which offshore Ekman transport and wind-induced turbulent mixing fall to coastwise minima specially during summer. The Brazil Current flows skirting across the bight opening rather than following the coastline into bight interior (Bakun \& Parrish, 1990). Four cruises were conducted with R/V "Prof. W. Besnard" during 1980 through 1982 in the Southeastern Brazilian Bight (Table 1, Fig. 1). During the cruise of October 1981, 19 samplings with bongo and neuston nets were made concurrently during 36 hours at the fixed station near Cabo Frio.

The neuston net was made at the "Instituto Oceanográfico da Universidade de São Paulo" based on the model of David (1965). It has a large frame of catamaran and sustains a small rectangular plankton net inside. The net has a mouth opening of $30 \mathrm{~cm} \times 20 \mathrm{~cm}$ and a length of $380 \mathrm{~cm}$ with $0.333 \mathrm{~mm}$ mesh size. Net towing was made at starboard with ship speed of about 1.5 and 2.0 knots during 10 minutes. The mouth of net cuts approximately $15 \mathrm{~cm}$ of surface layer, but because of a problem of irregular immersion of net during bad weather, no estimation of filtered water was made.

Beside the neuston net, bongo net sampling was made at the same station for comparative purpose. The bongo net has a mouth diameter of $60 \mathrm{~cm}$ with fine mesh net $(0.333 \mathrm{~mm})$ and coarse mesh net $(0.505 \mathrm{~mm})$ and only the samples collected with the coarse mesh net were used for comparison with neuston net samples. We followed the sampling procedure described by Smith \& Richardson
(1977). To measure filtered water volume, digital flowmeter was attached at the center of mouth opening.

The plankton samples were fixed immediately on board with $10 \%$ buffered formalin solution. In the laboratory, after measuring the plankton volume by the method of Kramer et al. (1972), fish eggs and larvae were sorted and later identified for family level. More abundant groups of fish larvae were identified for species level : 1) Sardinella brasiliensis, 2) Engraulis anchoita, 3) Harengula jaguana, 4) Maurolicus muelleri, 5) Auxis sp, 6) Bregmaceros cantori, 7) B. atlanticus, and 8) Katsuwonus pelamis. Notochord length (NL) and standard length (SL) were used for measurement of preflexion and flexion larvae and postflexion larvae, respectively.

\section{Results}

\section{Ocurrences of fish larvae observed by neuston net}

Taxonomic groups of fish larvae taken by the neuston net during the cruise of March 1982 are presented in Table 2. Total number of larvae caught during the cruise was separated according to time of day. Total number of taxa identified was 32 , having 23 taxa in night samples and 19 taxa in day samples. Following taxa were collected exclusively in night : Myctophidae, Gonostomatidae, Diodontidae, Anguiliformes, Syngnathidae, Trachinocephalus myops (Synodonthidae), Trichiuridae, Holocentridae and Scombridae. The groups taken only in day time were : Sardinella brasiliensis, Mugilidae, Engraulididae (excluding Engraulis anchoita), Hemirhamphidae, Synodus foetens (Synodonthidae), other Clupeidae, Ophidiidae and Lutjanidae.

Specimen of the most of groups were mainly collected during day time, having $89.7 \%$ (1288 larvae) of total larvae taken $(=1436)$. Chi-square test applied on the predominant groups showed only Myctophidae and Auxis sp (Scombridae) were significantly abundant during night ( $=5 \%$ significance level) and Exocoetidae occurred equally in both time periods. Nine abundant groups (Mullidae, Gerreidae, Harengula jaguana, Sardinella brasiliensis, Blenniidae, Engraulis anchoita, Mugilidae, other Engraulididae and Carangidae) were significantly abundant during day.

Table 1. Date and regions of sampling stations

Cruise

$$
\begin{aligned}
& \text { Number of samples } \\
& \text { Neuston }
\end{aligned}
$$

Number of fish larvae

Neuston Bongo

Survey area

3800

2329

4535

8467
Paranaguá-Florianópolis

Iguape

Cabo Frio (Fixed Station)

Cabo Frio-Paranaguá

March 1982 


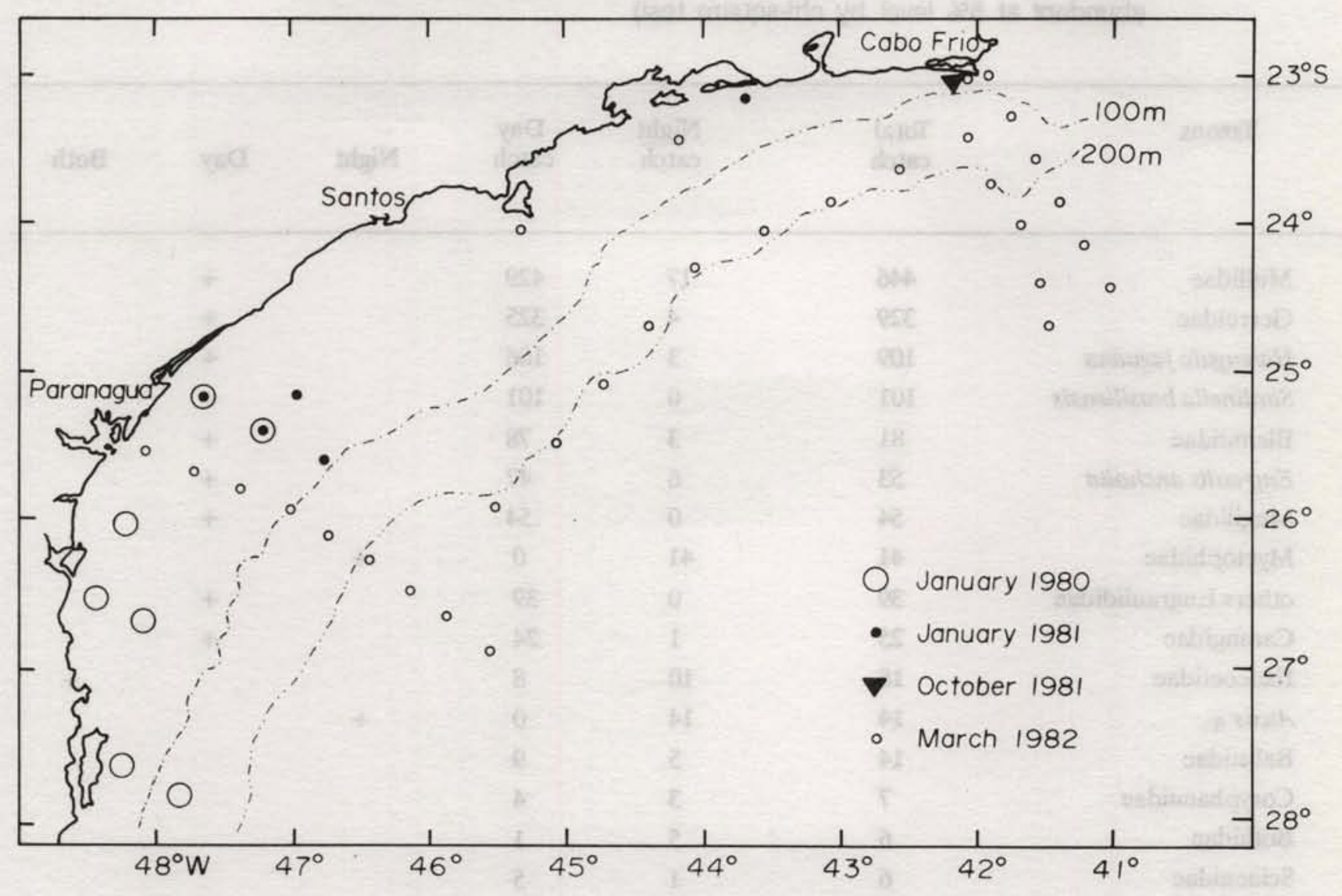

Fig. 1. Area and sampling stations of neuston and bongo nets by R/N. "Prof. W. Besnard" in the southeastern Brazilian Bight.

Larvae of three species (S. brasiliensis, H.jaguana and E. anchoita) collected during four cruises with neuston net were separated into night/day periods and size frequency distributions of two periods for three species are shown in Figures 2-4. More striking difference was observed in S. brasiliensis, having $1398(93 \%)$ taken during night and only $101(17 \%)$ taken during day. Size of sardine larvae ranged from 2.5 to $30.5 \mathrm{~mm} \mathrm{SL}$, but larvae ranging between 9.5 and $14.5 \mathrm{~mm}$ SL predominated the day samples, representing $80 \%$ of total larvae taken during day. On the other hand, size class between 21.5 and 25.5 $\mathrm{mm}$ SL predominated in night samples, occupying about $73 \%$ of total. Sardine larvae larger than $17.5 \mathrm{~mm}$ SL were taken exclusively in night.

In case of the scaled sardine ( $H$. jaguana), numbers of larvae taken during day and night showed small difference, having 140 larvae (58\%) during night and 101 larvae (42\%) during day. For the size range from 2.5 to $5.5 \mathrm{~mm} \mathrm{SL}$, there is no difference in day and night catches, but larger larvae ranging between 6.5 and $13.0 \mathrm{~mm}$ SL were predominantly taken in day and those between 11.0 and $17.5 \mathrm{~mm}$ SL in night (Fig. 3).
Number of anchoita (E. anchoita) larvae taken with neuston net during four cruises was smaller than those of two other species and most of them (129 larvae) were taken during night. Most larvae taken during night were smaller specimens, ranging from 3.0 to $7.0 \mathrm{~mm} \mathrm{SL}$ (Fig. 4).

\section{Comparison between neuston net and bongo net}

\section{a) Size frequency distributions of fish lavvae}

From total of 4172 sardine (S. brasiliensis) larvae, 2710 were taken with bongo net and 1546 with neuston net (Table 3). Sizes of larvae ranged from 2.5 to $28.5 \mathrm{~mm} \mathrm{SL}$ with bongo net and from 2.5 to $30.5 \mathrm{~mm} \mathrm{SL}$ with neuston net. Larvae smaller than $10.5 \mathrm{~mm}$ SL were predominantly collected with bongo net and those larger than $19.5 \mathrm{~mm}$ SL with neuston net (Fig. 5). Only small number of larvae ranging from $11.5 \mathrm{~mm}$ to $18.5 \mathrm{~mm} \mathrm{SL}$ were taken with both nets. 
Table 2. Taxonomic groups of fish larvae collected with neuston net during the cruise of March 1982, separated into night and day catches $(+=$ significantly more abundant at $5 \%$ level by chi-square test)

\begin{tabular}{|c|c|c|c|c|c|c|}
\hline Taxons & $\begin{array}{l}\text { Total } \\
\text { catch }\end{array}$ & $\begin{array}{l}\text { Night } \\
\text { catch }\end{array}$ & $\begin{array}{c}\text { Day } \\
\text { catch }\end{array}$ & Night & Day & Both \\
\hline Mullidae & 446 & 17 & 429 & & + & \\
\hline Gerreidae & 329 & 4 & 325 & & + & \\
\hline Harengula jaguana & 109 & 3 & 106 & & + & \\
\hline Sardinella brasiliensis & 101 & 0 & 101 & & + & \\
\hline Blenniidae & 81 & 3 & 78 & & + & \\
\hline Engraulis anchoita & 53 & 6 & 47 & & + & \\
\hline Mugilidae & 54 & 0 & 54 & & + & \\
\hline Myctophidae & 41 & 41 & 0 & + & & \\
\hline others Engraulididae & 39 & 0 & 39 & & + & \\
\hline Carangidae & 25 & 1 & 24 & & + & \\
\hline Exocoetidae & 18 & 10 & 8 & & & + \\
\hline Auxis sp. & 14 & 14 & 0 & + & & \\
\hline Balistidae & 14 & 5 & 9 & & & \\
\hline Coryphaenidae & 7 & 3 & 4 & & & \\
\hline Bothidae & 6 & 5 & 1 & & & \\
\hline Sciaenidae & 6 & 1 & 5 & & & \\
\hline Katsuwonus pelamis & 3 & 3 & 0 & & & . \\
\hline Diodontidae & 3 & 3 & 0 & & & \\
\hline Hemirhamphidae & 3 & 0 & 3 & bins? & $\operatorname{cinh}$ & \\
\hline others Scombridae & 3 & 3 & 0 & $\sin \sin ^{2}$ & 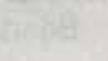 & \\
\hline Synodus foetens & 2 & 0 & 2 & & & \\
\hline others Clupeidae & 2 & 0 & 2 & & & \\
\hline Gonostomatidae & 2 & 2 & 0 & $1 \operatorname{lin}^{4} 2$ & $\sqrt{3}$ & bertens \\
\hline Anguiliformes & 2 & 2 & 0 & & & \\
\hline Syngnathidae & 2 & 2 & 0 & $a^{2} x$ & & \\
\hline Trachinocephalus myops & 1 & 1 & 0 & $8 \sin 1 / 2$ & $x^{2}$ & matits \\
\hline others mesopelagics & 1 & 1 & 0 & & & \\
\hline Ophidiidae & 1 & 0 & 1 & & & \\
\hline Trichiuridae & 1 & 1 & 0 & 712 & disiti & \\
\hline Holocentridae & 1 & 1 & 0 & $107 x$ & & \\
\hline Lutjanidae & 1 & 0 & 1 & 8 & & $=12$ \\
\hline not identified & 65 & 16 & 49 & 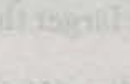 & & 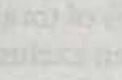 \\
\hline TOTAL & 1436 & 148 & 1288 & & 5 & 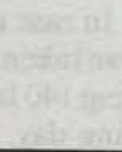 \\
\hline
\end{tabular}




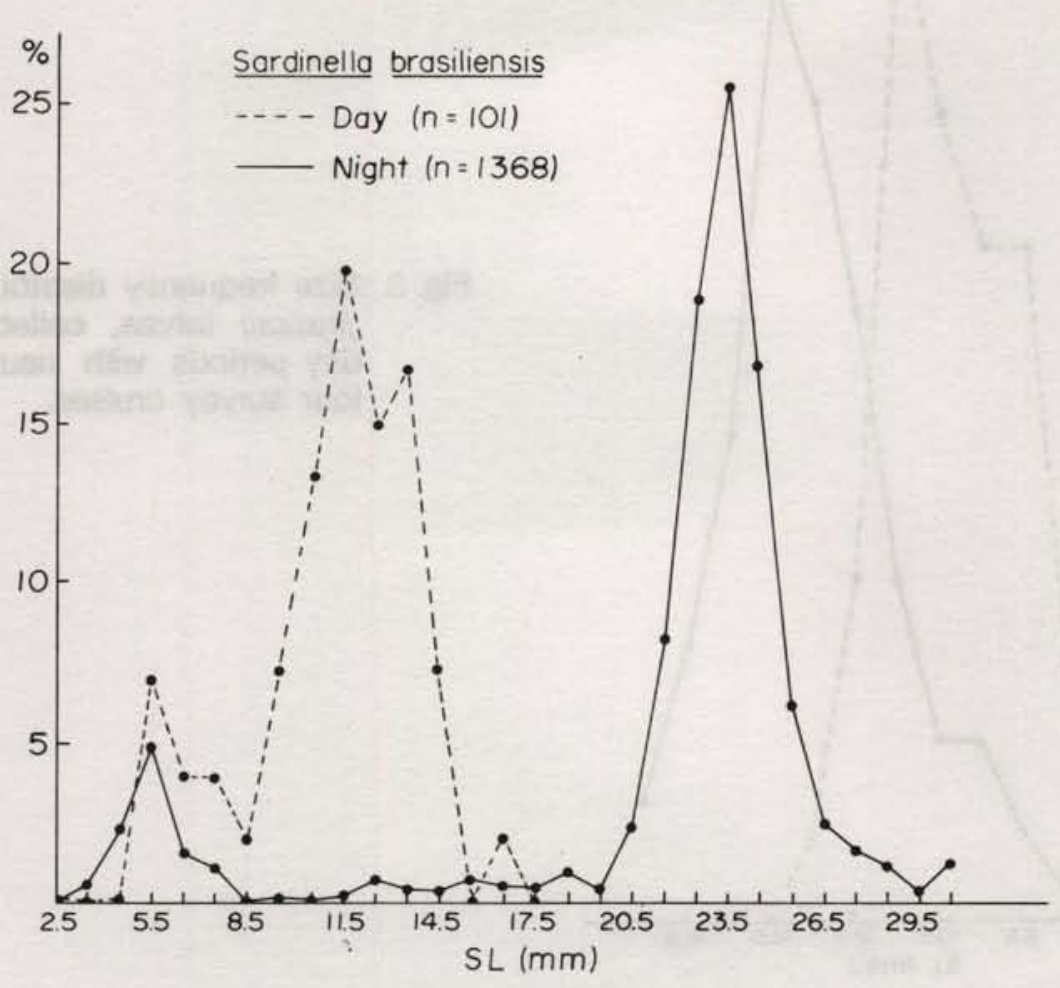

Fig. 2. Size frequency distribution of Sardinella brasiliensis larvae, collected at night and day periods with neuston net during four survey cruises.

Size of scaled sardine ( $H$. jaguana) ranged from 2.5 to $19.5 \mathrm{~mm} \mathrm{SL}$ in both nets and total numbers of larvae taken with two nets were similar (208 larvae with bongo versus 244 larvae with neuston). In average, larvae taken with neuston net were slightly larger than those taken with bongo net (Fig. 6).

Most of anchoita (E. anchoita) larvae were taken with bongo net (2008) and only 150 larvae were taken with neuston net. Size frequency of anchoita larvae collected with two nets showed predominance of small larvae $(<10$ $\mathrm{mm} \mathrm{SL}$ ) (Fig. 7).

\section{b) Comparison of variabilities in taxa}

Numbers of larvae of each taxon collected during 36 hours observation at the fixed station near Cabo Frio in October 1981 are shown in Table 4. From 33 taxa identified, Bregmaceros atlanticus was collected only with neuston net and other 32 taxa were collected with bongo net and/or neuston net. Total number of larvae taken with bongo net $(=4535$ larvae) exceeded that taken with neuston net ( $=384$ larvae). The most abundant group collected with bongo net was the family Engraulididae (including $E$. anchoita), contributing with $47.9 \%$ of total. Other abundant groups in bongo net samples were : Bothidae (6.3\%), Carangidae (6.2\%), Serranidae (5.0\%), Bregmaceros cantori (4.2\%), Cynoglossidae (2.8\%) and Sciaenidae (2.4\%). With neuston net, the more abundant taxa were as follows: Blenniidae (23.4\%), Engraulididae (including $E$. anchoita) (22.7\%), Gerreidae (11.2\%), Mugilidae (8.9\%) and Mullidae (6.8\%).

During the cruise of March 1982, 32 plankton samples of bongo net and the same number with neuston net were collected from which 11759 larvae were taken with bongo net and 2820 larvae with neuston net (Table 5). From 55 taxa identified, 53 taxa were taken with bongo net and only 22 taxa with neuston net. Three groups which appeared predominantly in bongo net samples were: Myctophidae $(24.6 \%)$, Gonostomatidae $(22.8 \%)$, and $E$. anchoita $(9.6 \%)$. With neuston net the following groups predominated: Mullidae (15.8\%), Gerreidae (11.7\%), $H$. jaguana $(3.9 \%)$ and $S$. brasiliensis (3.6\%). 


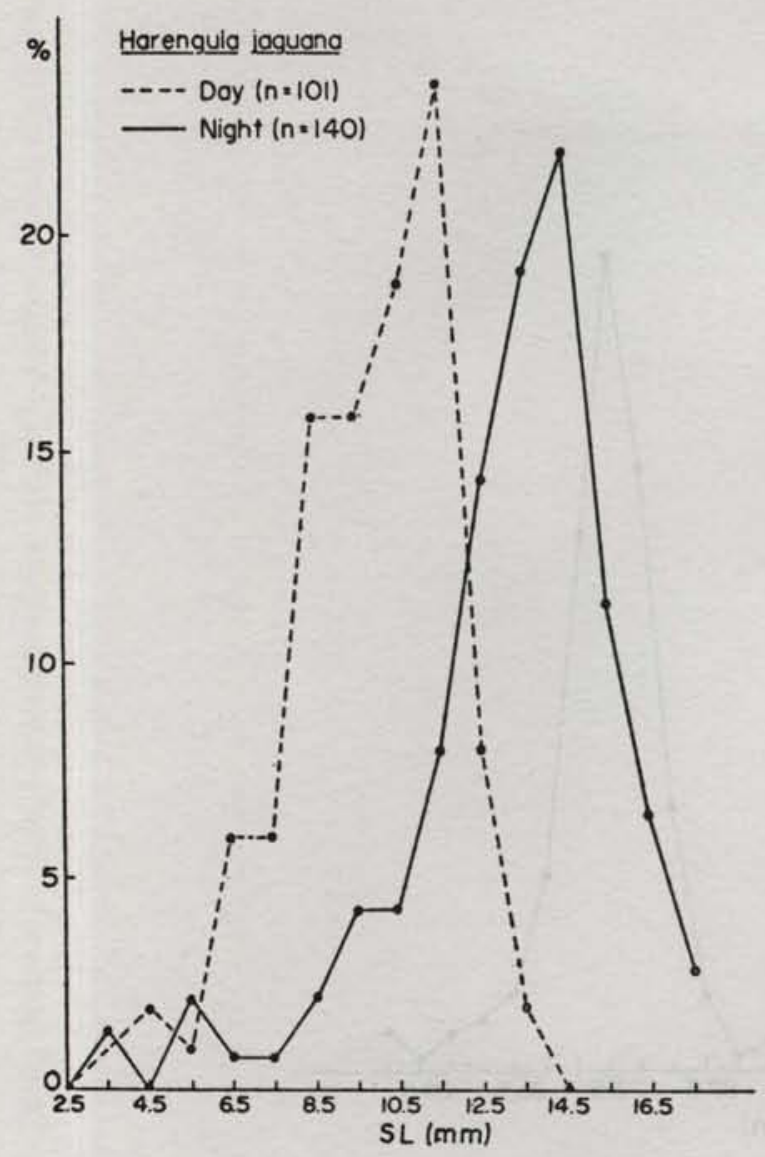

Fig. 3. Size frequency distribution of Harengula jaguana larvae, collected at night and day periods with neuston net during four survey cruises.

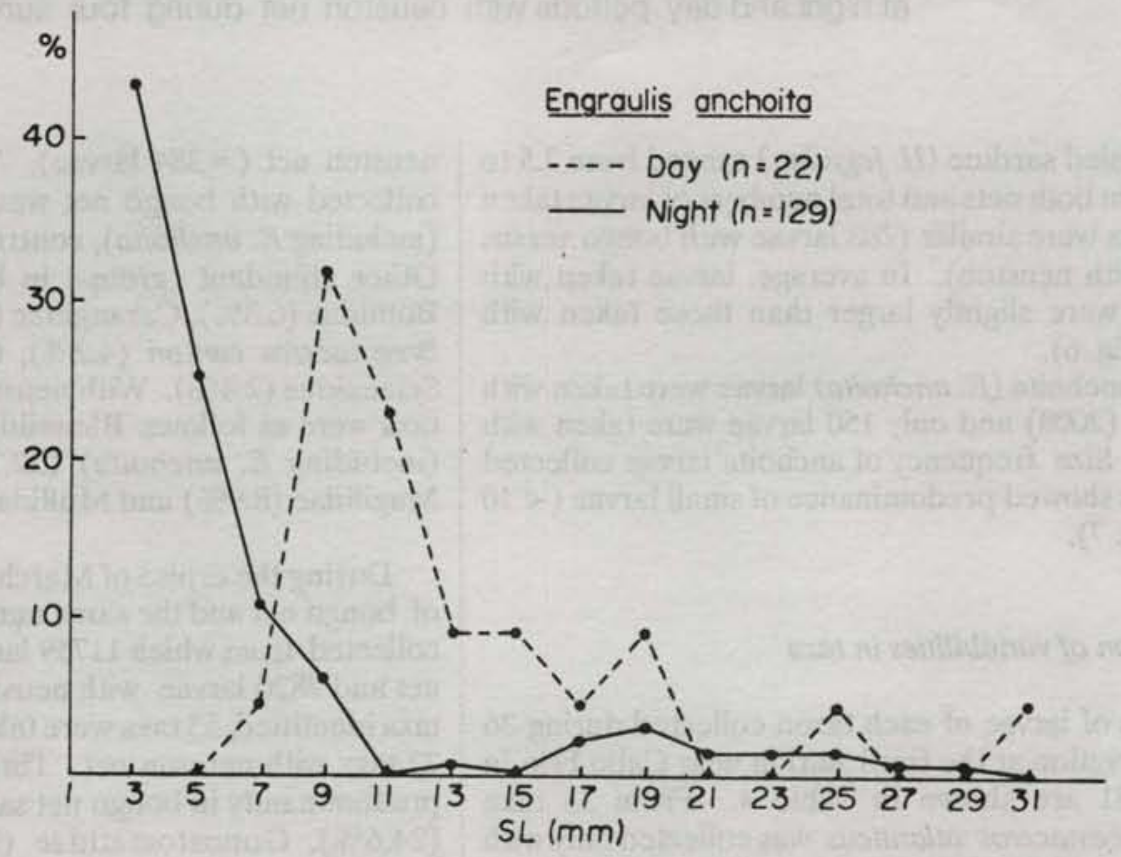

Fig. 4. Size frequency distribution of Engraulis anchoita larvae, collected at night and day periods with neuston net during four survey cruises. 


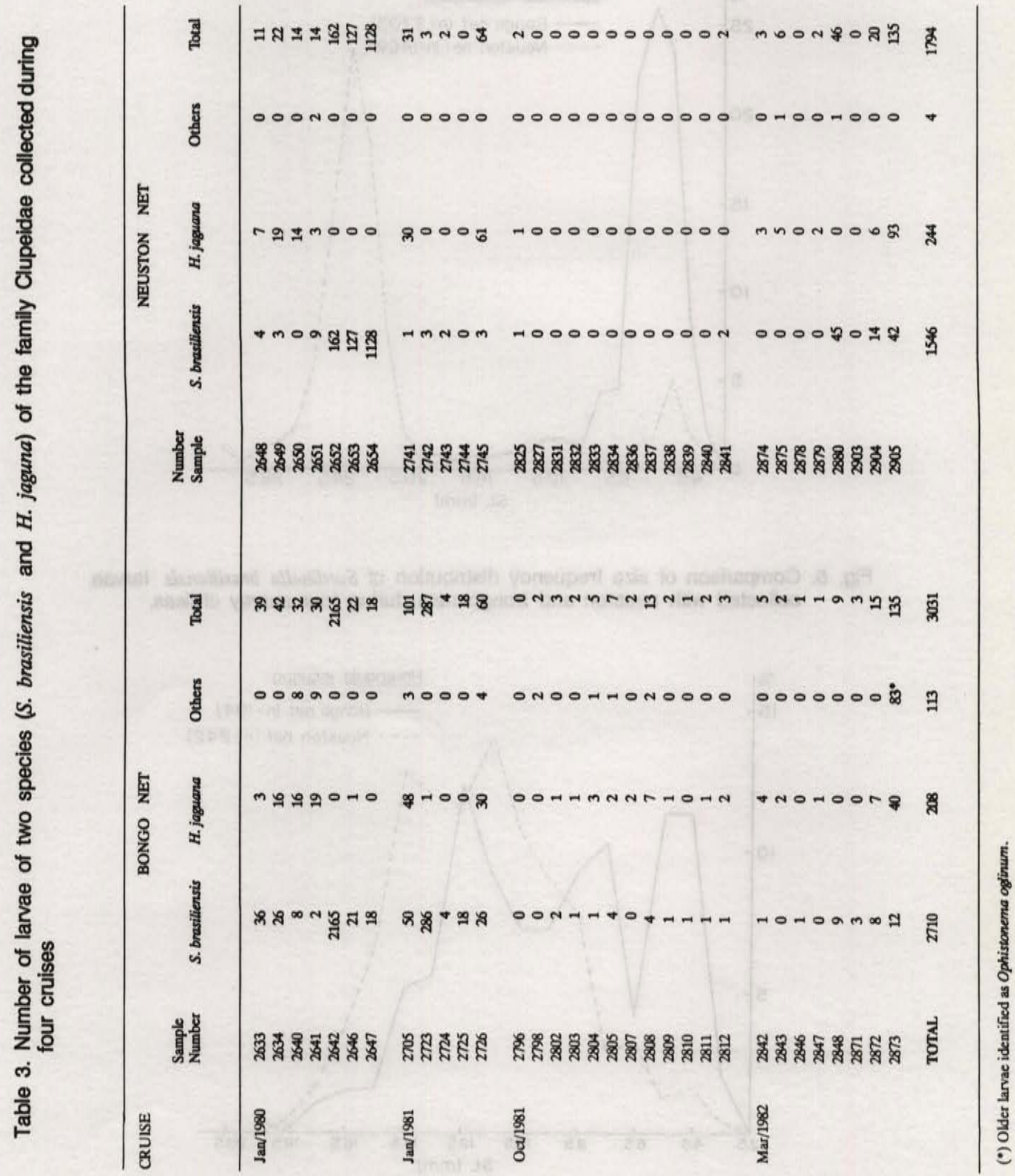




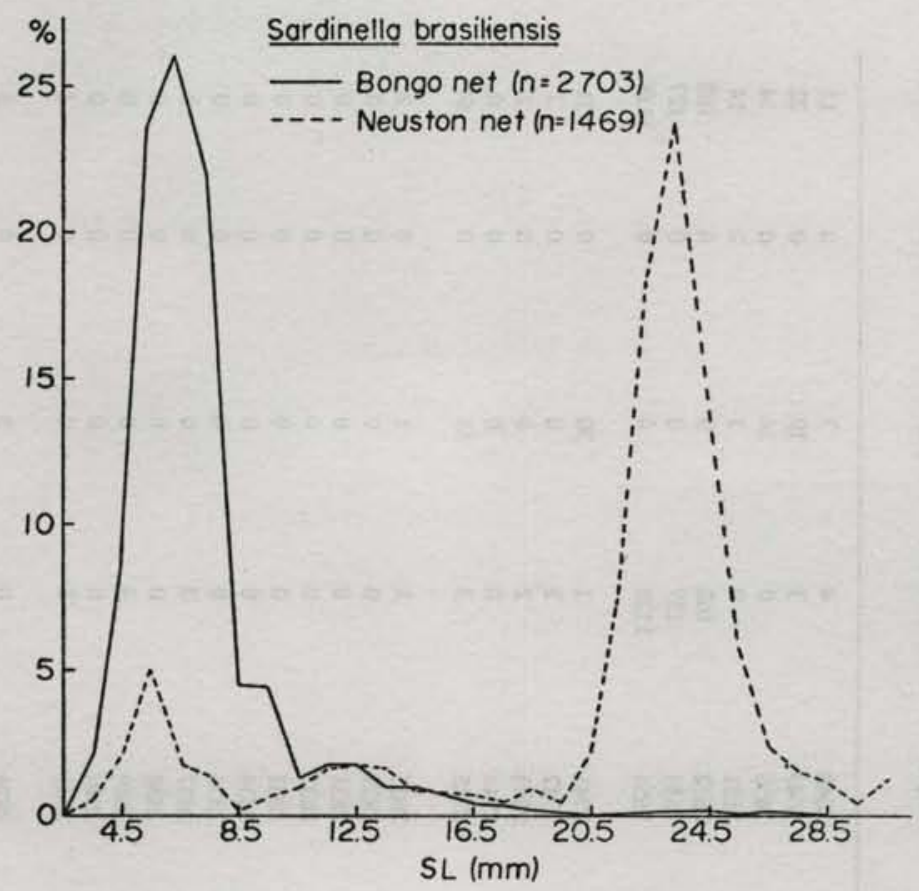

Fig. 5. Comparison of size frequency distribution of Sardinella brasiliensis larvae, collected with neuston and bongo nets during four survey cruises.

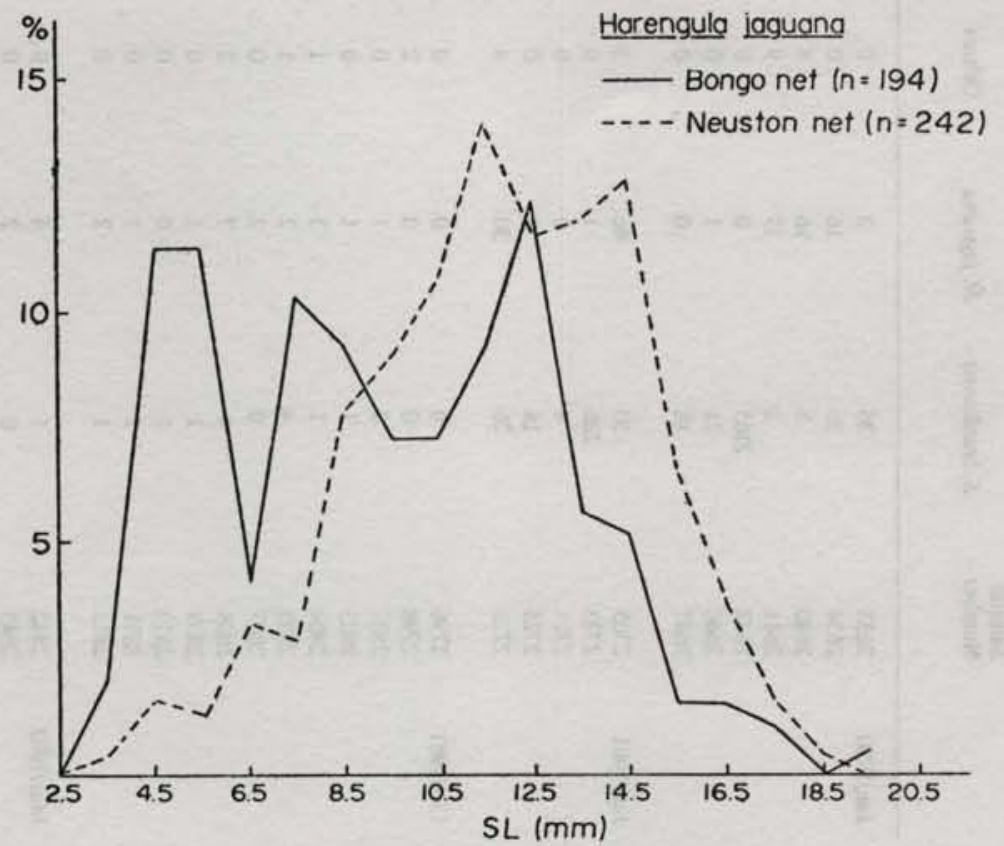

Fig. 6. Comparison of size frequency distribution of Harengula jaguana larvae, collected with neuston and bongo nets during four survey cruises. 


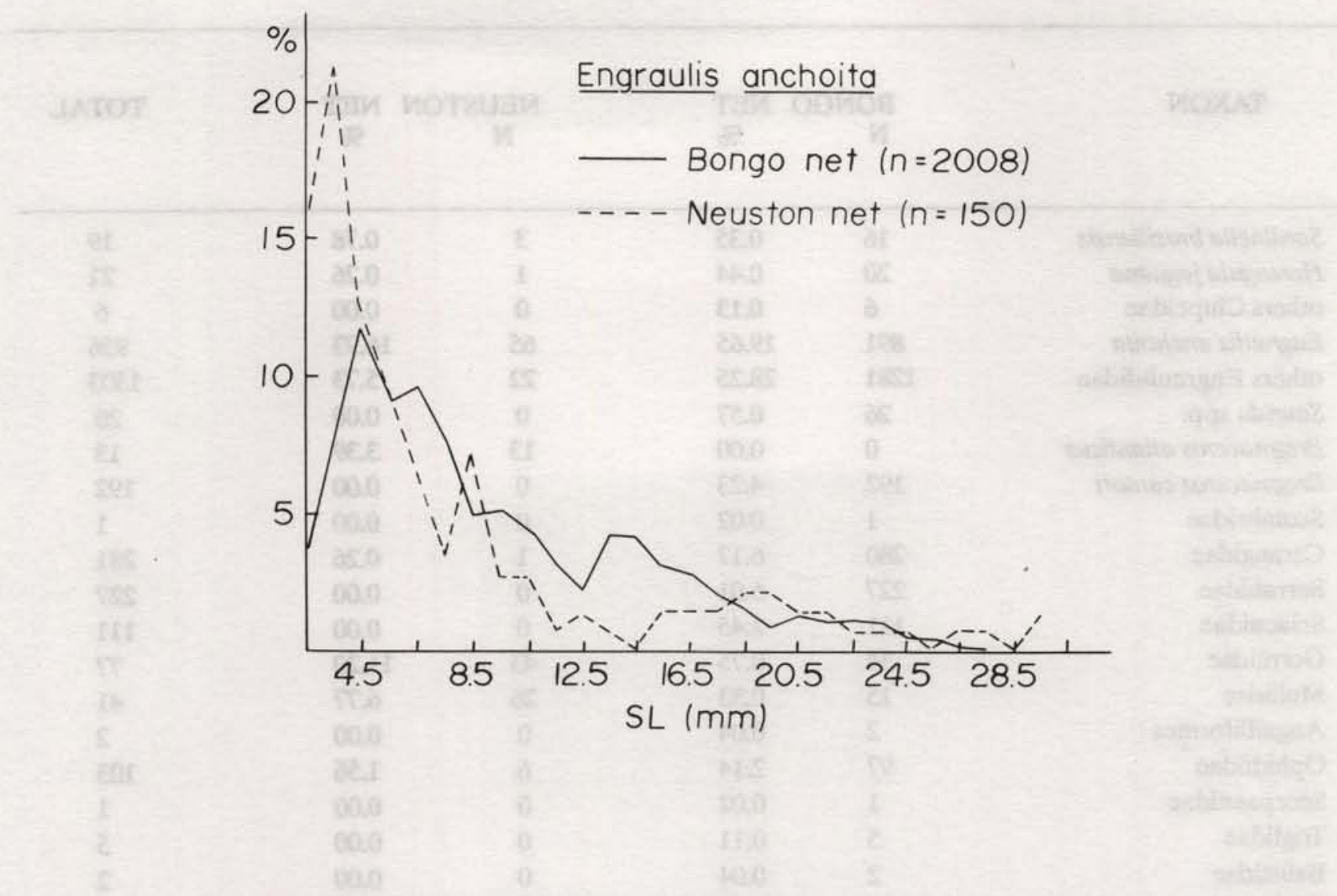

Fig. 7. Comparison of size frequency distribution of Engraulis anchoita larvae, collected with neuston and bongo nets during four survey cruises.

\section{Discussion}

Because of different sampling system (type of nets, towing time, filtered water volume, etc.), it was expected to obtain different larval abundances collected with two nets at the same stations. In fact, we obtained much more larvae in number and taxonomic groups with bongo net than with neuston net (Table 4 and 5). The similar kind of observation was made in the California Current region by Ahlstrom \& Stevensen (1975) and they suggested the samples collected only at surface layer were less representative than those obtained with oblique haul. On the other hand, when these values are expressed in relative frequency, we can observe different tendency of dominant groups which show different vertical distribution patterns. For example, the group of mesopelagic fish larvae (Myctophidae and Gonostomatidae) predominated in samples taken with bongo net, while the families Mullidae and Gerreidae were more abundant in neuston net samples during the cruise of March 1982.
From the results presented in Tables 4 and 5, we can consider the families Mullidae, Mugilidae and Exocoetidae as euneustonic, as observed by Hempel \& Weikert (1972), Zaitsev (1971), and Tully \& ÓCéidigh (1989). However, when we compare the same families collected in different time of day with neuston net (Table 2), only Exocoetidae was real euneuston and other two families were facultative neuston which occurred mainly during day. We can also consider the families Gerreidae and Blenniidae as facultative neustonic groups, but Eldridge et al. (1978) considered the Gerreidae as belonging to euneustonic group.

Vertical distribution pattern may vary considerably within the same species according to sampling place. For example, Hempel \& Weikert (1972) observed that the larvae of Scomber scombrus occurred in neustal during day in the North Sea, but they did occur in neustal during night in the Norwegian sea. In our samples, the species of the family Scombridae (Auxis sp, Katsuwonus pelamis, and other scombrids) occurred exclusively during night in neuston samples. 
Table 4. Comparison of catches with bongo net and neuston net at a fbed station near Cabo Frio in October 1981

\begin{tabular}{|c|c|c|c|c|c|}
\hline TAXON & $\begin{array}{l}\text { BONGO } \\
\mathrm{N}\end{array}$ & $\begin{array}{r}\text { NET } \\
\%\end{array}$ & $\begin{array}{l}\text { NEUSTON } \\
\mathbf{N}\end{array}$ & $\underset{\%}{\text { NET }}$ & TOTAL \\
\hline Sardinella brasiliensis & 16 & 0.35 & 3 & 0.78 & 19 \\
\hline Harengula jaguana & 20 & 0.44 & 1 & 0.26 & 21 \\
\hline others Clupeidae & 6 & 0.13 & 0 & 0.00 & 6 \\
\hline Engraulis anchoita & 891 & 19.65 & 65 & 16.93 & 956 \\
\hline others Engraulididae & 1281 & 28.25 & 22 & 5.73 & 1303 \\
\hline Saurida spp. & 26 & 0.57 & 0 & 0.00 & 26 \\
\hline Bregmaceros atlanticus & 0 & 0.00 & 13 & 3.39 & 13 \\
\hline Bregmaceros cantori & 192 & 4.23 & 0 & 0.00 & 192 \\
\hline Scombridae & 1 & 0.02 & 0 & 0.00 & 1 \\
\hline Carangidae & 280 & 6.17 & 1 & 0.26 & 281 \\
\hline Serranidae & 227 & 5.01 & 0 & 0.00 & 227 \\
\hline Sciaenidae & 111 & 2.45 & 0 & 0.00 & 111 \\
\hline Gerreidae & 34 & 0.75 & 43 & 11.20 & 77 \\
\hline Mullidae & 15 & 0.33 & 26 & 6.77 & 41 \\
\hline Anguilliformes & 2 & 0.04 & 0 & 0.00 & 2 \\
\hline Ophidiidae & 97 & 2.14 & 6 & 1.56 & 103 \\
\hline Scorpaenidae & 1 & 0.02 & 0 & 0.00 & 1 \\
\hline Triglidae & 5 & 0.11 & 0 & 0.00 & 5 \\
\hline Balistidae & 2 & 0.04 & 0 & 0.00 & 2 \\
\hline Trichiuridae & 3 & 0.07 & 0 & 0.00 & 3 \\
\hline Blenniidae & 95 & 2.09 & 90 & 23.44 & 185 \\
\hline Sphyraenidae & 3 & 0.07 & 0 & 0.00 & 3 \\
\hline Tetraodontidae & 1 & 0.02 & 0 & 0.00 & 1 \\
\hline Percophididae & 3 & 0.07 & 0 & 0.00 & 3 \\
\hline Lophidae & 2 & 0.04 & 3 & 0.78 & 5 \\
\hline Stromateidae & 1 & 0.02 & 0 & 0.00 & 1 \\
\hline Gadidae & 1 & 0.02 & 0 & 0.00 & 1 \\
\hline Mugilidae & 4 & 0.09 & 34 & 8.85 & 38 \\
\hline Syngnatidae & 49 & 1.08 & 0 & 0.00 & 49 \\
\hline Bothidae & 287 & 6.33 & 1 & 0.26 & 288 \\
\hline Cynoglossidae & 126 & 2.78 & 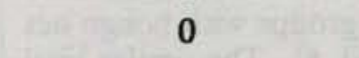 & 0.00 & 126 \\
\hline others Pleuronectiformes & 44 & 0.97 & 0 & 0.00 & 44 \\
\hline Gobiidae & 23 & 0.51 & 0 & 0.00 & 23 \\
\hline not identified & 686 & 15.13 & $x=5$ & 19.79 & 762 \\
\hline TOTAL & 4535 & & 384 & & 4919 \\
\hline
\end{tabular}


Table 5. Comparison of fish lavae taken with Bongo net and neuston net during the cruise of March 1982

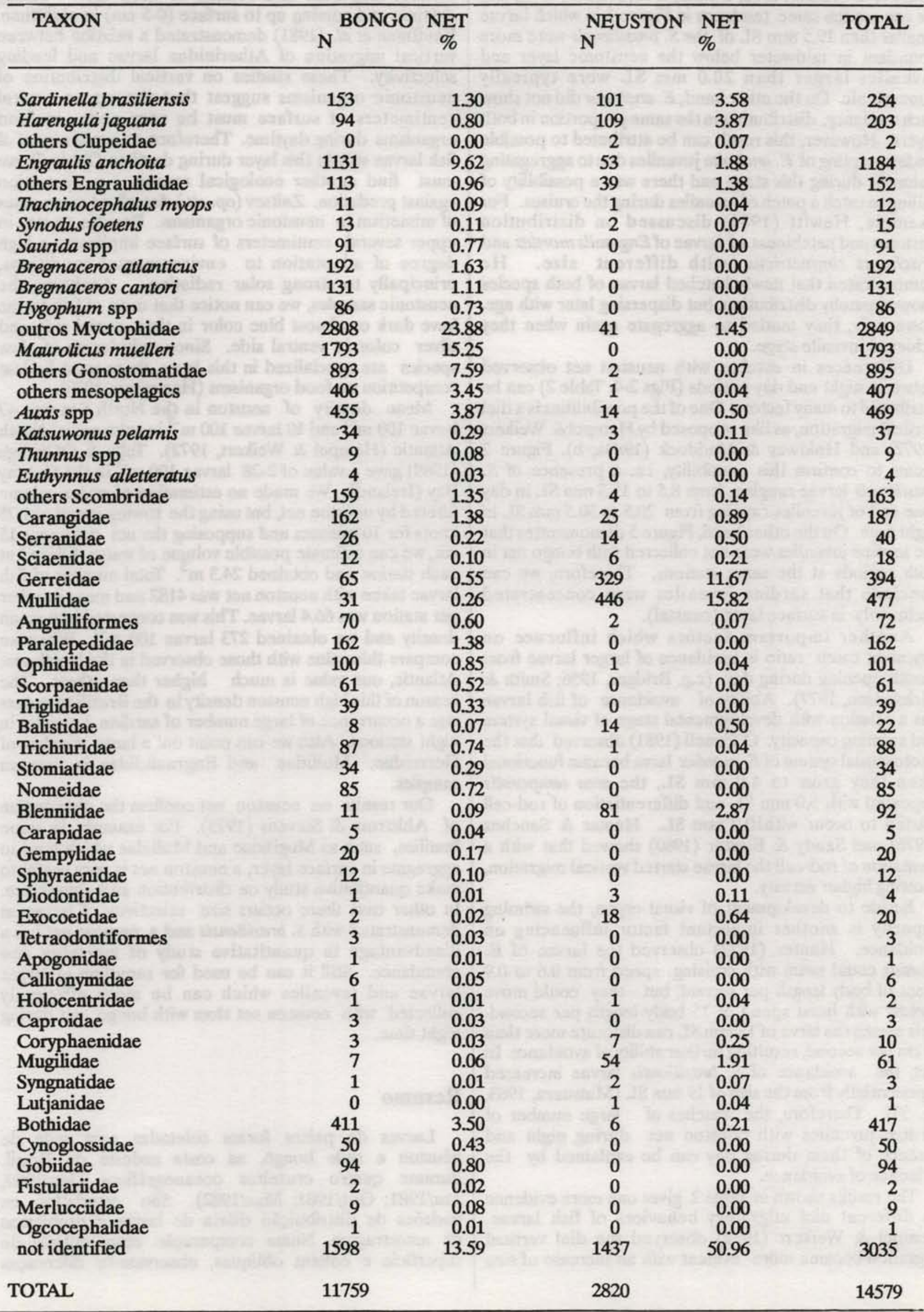


Vertical distribution patterns of different size classes also showed considerable variation in some species (Blaxter \& Hunter, 1982; Uotani, 1973; Hunter, 1976) and we can see the same tendency in Figure 5 in which larvae smaller than $19.5 \mathrm{~mm}$ SL of the $S$. brasiliensis were more abundant in midwater below the neustonic layer and juveniles larger than $20.0 \mathrm{~mm}$ SL were typically euneustonic. On the other hand, $E$. anchoita did not show such tendency, distributing in the same proportion in both layers. However, this result can be attributed to possible undersampling of $E$. anchoita juveniles due to aggregating behavior during this stage and there was a possibility of failing to catch a patch of juveniles during the cruises. For example, Hewitt (1981) discussed on distribution patterns and patchiness of larvae of Engraulis mordax and Trachurus simmetricus with different size. $\mathrm{He}$ demonstrated that newly hatched larvae of both species showed patchy distribution, but dispersing later with age. Posteriorly, they tended to aggregate again when they achieved juvenile stage.

Differences in catches with neuston net observed between night and day periods (Figs 2-4, Table 2) can be attributed to many factors. One of the possibilities is a diel vertical migration, as like proposed by Hempel \& Weikert (1972) and Holdway \& Maddock (1983a; b). Figure 2 seems to confirm this possibility, i.e. a presence of $S$. brasiliensis larvae ranging from 8.5 to $15.5 \mathrm{~mm} \mathrm{SL}$ in day time and of juveniles ranging from 20.5 to $30.5 \mathrm{~mm} \mathrm{SL}$ in night time. On the other hand, Figure 5 demonstrates that the sardine juveniles were not collected with bongo net in both periods at the same stations. Therefore, we can conclude that sardine juveniles were concentrated exclusively in surface layer (neustal).

Another important factors which influence on day/night catch ratio is avoidance of larger larvae from mouth opening during day (e.g. Bridger, 1956; Smith \& Richardson, 1977). Ability of avoidance of fish larvae has a relation with developmental stage of visual system and swiming capacity. O'Conell (1981) observed that the photosensial system of $E$. mordax larva became functional when they grow to $4.0 \mathrm{~mm} \mathrm{SL}$, the area temporalis appeared with $5.0 \mathrm{~mm} \mathrm{SL}$ and differentiation of rod-cell started to occur with $10.0 \mathrm{~mm} \mathrm{SL}$. Hunter \& Sanchez (1976) and Sandy \& Blaxter (1980) showed that with a formation of rod-cell the larvae started vertical migration, showing higher activity.

Beside to development of visual organ, the swiming capacity is another important factor influencing on avoidance. Hunter (1972) observed the larvae of $E$. mordax could swim with cruising speed from 0.6 to 0.9 times of body length per second, but they could move rapidly with burst speed of 15 body length per second. This means the larva of $15 \mathrm{~mm} \mathrm{SL}$ can dislocate more than $20 \mathrm{~cm}$ per second, resulting further ability of avoidance. In fact, the avoidance of $S$. brasiliensis larvae increased exponentially from the size of $19 \mathrm{~mm} \mathrm{SL}$ (Matsuura, 1983, fig. 53). Therefore, the catches of large number of sardine juveniles with neuston net during night and absence of them during day can be explained by the influence of avoidance.

The results shown in Table 2 gives one more evidence on different diel migratory behaviors of fish larvae. Hempel \& Weikert (1972) observed the diel vertical migration became more evident with an increase of size and age and it was related to feeding behavior. According to Zaitsev (1971) many epipelagic organisms do diel vertical migration and remain in deep layer during daytime and coming up to surface $(0-5 \mathrm{~cm})$ in nighttime. Kauffman et al. (1981) demonstrated a relation between vertical migration of Atherinidae larvae and feeding selectivity. These studies on vertical distribution of neustonic organisms suggest that the upper several centimeters of surface must be very poor in food organisms during daytime. Therefore, to explain most of fish larvae stay in this layer during daytime (Table 2), we must find another ecological reason, e.g. protection against predation. Zaitsev (op. cit.) described many cases of mimetism in neustonic organisms. Besides, to stay in upper several centimeters of surface implicates a high degree of adaptation to environmental conditions, principally to strong solar radiation. Analyzing the neustonic samples, we can notice that most of fish larvae have dark or almost blue color in their dorsal side and silver color in ventral side. Since only larvae of few species are specialized in this layer, there must be less competition on food organisms (Hartmann, 1970).

Mean density of neuston in the North Sea was 47 larvae $100 \mathrm{~m}^{-3}$ and 10 larvae $100 \mathrm{~m}^{-3}$ in subtropical North Atlantic (Hempel \& Weikert, 1972). Tully \& ÓCéidigh (1989) gave a value of $2-28$ larvae $100 \mathrm{~m}^{-3}$ in the Galway Bay (Ireland). We made no estimation of water volume filtered by neuston net, but using the towing speed of 1.75 knots for 10 minutes and supposing the net cut upper 15 $\mathrm{cm}$, we can estimate possible volume of water filtered at each station and obtained $24.3 \mathrm{~m}^{3}$. Total number of fish larvae taken with neuston net was 4182 and mean number per station was 66.4 larvae. This was converted into mean density and we obtained 273 larvae $100 \mathrm{~m}^{-3}$. When we compare this value with those observed in the Northwest Atlantic, our value is much higher than others. The reason of this high neuston density in the Brazilian waters was a occurrence of large number of sardine juveniles in night stations. Also we can point out a large number of Gerreidae, Mullidae and Engraulididae in neuston samples.

Our results on neuston net confirm the observation of Ahlstrom \& Stevens (1975). For example, in some families, such as Mugilidae and Mullidae which tend to aggregate in surface layer, a neuston net is very useful to make quantitative study on distribution and abundance. In other case there occurs size selectivity of larvae as demonstrated with $S$. brasiliensis and a neuston net has a disadvantage in quantitative study of mortality and abundance. Still it can be used for sampling of larger larvae and juveniles which can be more efficiently collected with neuston net than with bongo net during night time.

\section{Resumo}

Larvas de peixes foram coletadas com rede de nêuston e rede bongô, na costa sudeste do Brasil, durante quatro cruzeiros oceanográficos (Jan/1980; Jan/1981; Out/1981; Mar/1982). São estudados os padrōes de distribuiçāo diária de larvas e problemas de amostragem. Numa comparação entre coletas de superfície e coletas oblíquas, observam-se diferenças 
em composição, tanto em termos de espécies como de tamanho de larvas. Pode ser observada uma clara tendência de estratificação por composição de tamanho para Sardinella brasiliensis em que espécimes juvenis ( $>19 \mathrm{~mm}$ ) ocorreram preferencialmente na camada superficial. Estes juvenis também apresentaram maior capacidade de fuga da boca da rede durante o período diurno. A maioria dos táxons de ocorrência neustônica foi também capturada em camadas mais profundas, mas alguns grupos como Mugilidae, Mullidae e Gerreidae predomiram na camada superficial. A densidade do ictionêuston é mais elevada na nossa região do que a observada no Atlântico noroeste, e o número de larvas de peixes da coleta diuna com rede de nêuston excedeu o da coleta noturna.

\section{Acknowledgements}

Financial support for this investigation came from the Financiadora de Estudos e Projetos (FINEP). The senior author received the scholarship of the Fundação de Amparo à Pesquisa do Estado de São Paulo (FAPESP) and the junior author received the research fellowship of the Conselho Nacional de Desenvolvimento Científico e Tecnológico (CNPq) during this study.

\section{References}

AHLSTROM, E. H. \& STEVENS, E. 1975. Report of neuston (surface) collection made on an extended CalCOFI cruise during May 1972. CalCOFI Rept, 18:167-180.

BAKUN, A. \& PARRISH, R.H. 1990. Comparative studies of coastal pelagic fish reproductive habitats: the Brazilian sardine (Sardinella aurita). J. Cons. perm. int. Explor. Mer, 46:269-283.

BLAXTER, J.H.S. \& HUNTER, J.R. 1982. The biology of the clupeid fishes. Adv. mar. Biol., 19:1-223.

BROWN, D.M. \& CHENG, L. 1981. New net for sampling the ocean surface. Mar. Ecol-Prog. Ser., 5: 225-227.

BRIDGER, J.P. 1956. On day and night variations in catches of fish larvae. J. Cons. perm. int. Explor. Mer, 22(1):42-57.

CHAMPALBERT, G. 1980. Les peuplements de l'écosystéme neustonique. Océanis, 6(2):205-211.

DAVID, P.M. 1965. The neuston net: a device for sampling the surface fauna of the ocean. J. mar. biol. Ass. U.K., 45(2):313-320.
ELDRIDGE, P. J.; BERRY, F. H. \& MILLER III, M. C., 1978. Diurnal variations in catches of selected species of ichthyoneuston by Boothbay neuston net off Charleston, South Carolina. Fishery Bull. natn. mar. Fish. Serv., U.S., 76(1):295-297.

GRUBER, D.; AHLSTROM, E. H. \& MULLIN, M. M., 1982. Distribution of ichthyoplankton in the Southern California Bight. Rept. Calif. coop. ocean. Fish. Invest., 23:172-179.

HARTMANN, J. 1970. Juvenile saury pike (Scomberesox saurus Walb.), an example of ichthyoneuston. J. Cons. perm. int. Explor. Mer, 33 (2):245-255.

HEMPEL, G. \& WEIKERT, H. 1972. The neuston of the subtropical and boreal Northeastern Atlantic Ocean, a review. Mar. Biol., 13(1):70-88.

HEWITT, R. 1981. The value of pattern in the distribution of young fish. Rapp. P-v. Réun. Cons. perm. int. Explor. Mer., 178:229-236.

HOLDWAY, P. \& MADDOCK, L. 1983a. A comparative survey of neuston: geographical and temporal distribution patterns. Mar.Biol. 76:263-270.

\& distributions. Mar. Biol, 77:207-214. 1983b. Neustonic

HUNTER, J. R. 1972. Swimming and feeding behavior of larval anchovy Engraulis mordax. Fishery Bull., natn mar. Fish. Serv., U.S., 70(3): 821-838.

1976. Culture and growth of northern anchovy, Engraulis mordax, larvae. Fishery Bull., natn. mar. Fish. Serv., U.S., 74(1):81-88.

\& SANCHEZ, C. 1976. Diel changes in swim bladder infration of the larvae of the northern anchovy, Engraulis mordax. Fishery Bull., natn. mar. Fish. Serv., U.S., 76(4):847-855.

JOHN, H.-CH. 1981. Ichthyoneuston of Cape Verde Archipelago. Rapp. P.v. Réun. Cons. perm. int. Explor. Mer, 178:237-239.

KAUFFMAN, T. A.; LINDSAY, J. \& LEITHISER, R., 1981. Vertical distribution and food selection of larval atherinids. Rapp. P.-v. Réun. Cons. perm. int. Explor. Mer, 178:342-343.

KRAMER, D.; KALIN, M. J.; STEVENS, E. G.; THAIKILL, J. R. \& ZWEIFEL, J. R. 1972. Collecting and processing data on fish eggs and larvae in the California Current region. NOAA Tech. Rept., natn. mar. Fish. Serv. Circ., (370): 1-38.

LEVINTON, J. S. 1982. Marine ecology. New Jersey. Prentice-Hall. 526p. 
MATSUO, Y.; NEMOTO, T. \& MARUMO, R. 1976. A convertible neuston net for zooplankton. Bull. Plankt. Soc. Japan, 23(1):26-30.

MATSUURA, M. 1983. Estudo comparativo das fases iniciais do ciclo de vida da sardinha-verdadeira, Sardinella brasiliensis e da sardinha-cascuda, Harengula jaguana (Pisces: Clupeidae) e nota sobre a dinâmica da populaçāo da sardinha-verdadeira na região sudeste do Brasil. Tese de livre-docência. Universidade de SãoPaulo, Instituto Oceanográfico. 150p. + tabs + figs.

O'CONELL, C. P. 1981. Development of organ systems in the northern anchovy, Engraulis mordax and other teleosts. Am. Zool., 21:429-446.

POWLES, H. 1981. Distribution and movements of neustonic young of estuarine dependent (Mugil spp., Pomatomus saltatrix) and estuarine independent (Coryphaena spp.) fishes off the Southeastern United States. Rapp. P.-v. Réun. Cons. perm. int. Explor. Mer, 178:207-209.

SAMEOTO, D. D. \& JAROSZYMSKI, L. O. 1969. Otter surface sampler: a new neuston net. J. Fish. Res. Bd Can., 26(8):2240-2244.

SANDY, J. M. \& BLAXTER, J. H. S. 1980. A study of retinal development in larval herring and sole. J. mar. biol. Ass. U.K., 60:59-71.
SCHRAM, T. A.; SVELLE, M. \& OPSAHL, M. 1981. A new divided neuston sampler in two modifications: description, tests, and biological results. Sarsia, 66(4):273-282.

SMITH, P.E. \& RICHARDSON, S.L. 1977. Standard techniques for pelagic fish egg and larva surveys. FAO Fish. tech. Pap., (175):1-100.

TULLY, O. \& OCÉIDIGH, P. 1989. The ichthyoneuton of Galway Bay (Ireland). I. The seasonal, diel and spatial distribution of larval, post-larval and juvenile fish. Mar. Biol., 101(1):27-41.

UOTANI, I. 1973. Diurnal changes of gas bladder and behaviour of postlarval anchovy and other related species. Bull. japan. Soc. scient. Fish., 39(8):867-876.

ZAITSEV, Yu. P. 1971. Marine neustonology; translated into English from Russian edition of 1970 by A. Mercado. Jerusalem, Israel Program for Scientific Translations. 207p.

(Received 14May-90; accepted 28-Nov-90) 